\title{
REVISITING THE VALUE ADDED TAX: A CLEAR SOLUTION TO THE MURKY UNITED STATES CORPORATE TAX STRUCTURE
}

\author{
Charles C. Engel, II
}

\section{INTRODUCTION}

The United States has the second highest combined federal-state corporate tax rate in the world. ${ }^{1}$ With an average combined rate of 39.3 percent, the U.S. effective corporate tax rate is fifty percent higher than the average of all States party to the Organisation for Economic Co-operation and Development (OECD). ${ }^{2}$ And while the United States maintains its high corporate tax rates, other industrialized nations are cutting theirs. ${ }^{3}$ Of the OECD's thirty Member States, nine cut their corporate tax rates between 2007 and $2008,{ }^{4}$ and the OECD Member with the highest corporate tax rate, Japan, has considered a rate cut as well. ${ }^{5}$

A high corporate tax rate can stunt a nation's economic growth and harm its economy. ${ }^{6}$ A study of fifty thousand companies in the European Union (EU) found that, when countries raise the marginal corporate tax rate by 1 percent, real wages decrease by 0.92 percent. ${ }^{7}$ Further, studies suggest that the United States government loses one dollar in revenue for each dollar collected from the corporate tax as a result of the country's sluggish economy. ${ }^{8}$ In reaction to these corporate tax-created problems, many U.S. corporations use creative accounting methods to move their profits overseas, thereby taking advantage of the

* J.D., 2012, Indiana University Robert H. McKinney School of Law, Indianapolis, Indiana; B.S., B.A., 2008, Indiana University, Bloomington, Indiana.

1. Scott A. Hodge, U.S. Corporate Taxes Now 50 Percent Higher than OECD Average, TAX FOUNDATION (Aug. 13, 2008), http://www.taxfoundation.org/publications/ show/23470.html.

2. Id.

3. James Pethokoukis, 20 Reasons to Kill Corporate Taxes, U.S. NEWS \& WORLD REP. (Aug. 22, 2008), http://money.usnews.com/money/blogs/capital-commerce/2008/8/22/20reasons-to-kill-corporate-taxes.html.

4. Id. They are: Canada, Germany, New Zealand, Spain, the United Kingdom, Italy, Switzerland, the Czech Republic, and Iceland. Id.

5. Id.

6. See generally Åsa Johansson et al., Tax and Economic Growth (Org. for Econ. Cooperation and Dev.: Econ. Dep't Working Paper No. 620, 2008), available at http://www.oecd.org/dataoecd/58/3/41000592.pdf.

7. Pethokoukis, supra note 3.

8. Id. 
comparatively low tax rates of other nations. ${ }^{9}$ These income-shifting strategies cost the United States government approximately $\$ 60$ billion per year. ${ }^{10}$

The United States cannot afford for companies to save billions of dollars at the expense of the American taxpayer-the government's fiscal gap is growing by the hour. ${ }^{11}$ The 2009 U.S. budget deficit was $\$ 1.4$ trillion and is expected to be $\$ 1.6$ trillion in $2010 .{ }^{12}$ On October 25,2010 , the U.S. national debt was $\$ 13.6$ trillion ${ }^{13}$ and is expected to reach $\$ 13.8$ trillion by the end of $2010 .{ }^{14}$ This already bleak financial outlook has been aggravated by "the worst financial crisis [in the United States] since the Great Depression." mortgage meltdown of 2007 and the subsequent financial crisis resulted in massive spending by the United States government, including the Trouble Assets Relief Program (TARP), a $\$ 787$ billion stimulus, bailouts for General Motors and Chrysler, and increased unemployment benefits. ${ }^{16}$ The financial crisis also decreased the nation's economic output between 2008 and 2010, resulting in fewer tax revenues for the government. ${ }^{17}$

While the financial crisis took a toll on the United States Budget, the looming liabilities of U.S. entitlement programs pose greater and longer-lasting

9. Jesse Drucker, Google 2.4\% Rate Shows How $\$ 60$ Billion Lost to Tax Loopholes, BLOOMBERG (Oct. 21, 2010), http://www.bloomberg.com/news/2010-10-21/google-2-4-rateshows-how-60-billion-u-s-revenue-lost-to-tax-loopholes.html.

10. Id.

11. See U.S. DebT Clock, http://www.usdebtclock.org/ (last visited Aug. 1, 2012). A country's fiscal gap is the "present-value measure of the country's fiscal imbalance." Calculating the Fiscal Gap, CONG. BUDGET OFF. (June 26, 2009), http://www.cbo.gov/ publication/24929. The fiscal gap represents the amount the government would need to raise in order to make its debt the same size at the end of a given year as it was at the beginning of that year. See id.

12. Cait Murphy, VAT: Will the U.S. Adopt a Value-Added Tax?, CBS MONEY WATCH (Apr. 7, 2010), http://www.cbsnews.com/8301-503983_162-20001918-503983.html. A budget deficit "occurs when [a government] has more money going out than coming in." Budget Deficit Definition, INVESTOPEDIA, http://www.investopedia.com/terms/b/budget-deficit.asp (last visited Aug. 1, 2012).

13. U.S. National Debt by Day, U.S. DeBT CLOCK, http://www.usadebtclock.com/usnational-debt-by-day.php (last updated May 29, 2012). The national debt is "the total amount of money that the United States federal government owes to creditors." Federal Debt Definition, INVESTOPEDIA, http://www.investopedia.com/terms/f/federaldebt.asp\#axzzlwTGSW3QH (last visited Aug. 1, 2012).

14. Murphy, supra note 12.

15. Jon Hilsenrath et al., Worst Crisis Since '30s, With No End Yet in Sight, Wall St. J. (Sept. 18, 2008), http://online.wsj.com/article/SB122169431617549947.html.

16. Economic Crisis and Market Upheavals, N.Y. TIMES, http://topics.nytimes.com/top/ reference/timestopics/subjects/c/credit_crisis/index.html (last updated Oct. 3, 2011).

17. See United States GDP Growth Rate, TRADING ECoN., http://www.tradingeconomics.com/Economics/GDP-Growth.aspx?Symbol=USD (last visited Aug. 1, 2012). 
challenges. ${ }^{18}$ Over the next few decades, as the "Baby Boomer" generation becomes eligible for Social Security and Medicare, the cost of these programs will rise from 8.4 percent of Gross National Product (GDP) ${ }^{19}$ to 18.6 percent. ${ }^{20}$ Using only the federal income tax to pay for the proposed benefits "would require raising the 35 percent income tax bracket to at least 77 percent and raising the 25 percent tax bracket to at least 55 percent. ${ }^{, 21}$ Although sensible proposals for entitlement reform exist, ${ }^{22}$ it is likely that other sources of revenue will be needed to pay for the tsunami of Baby Boomers who will eventually draw from Social Security and Medicare. ${ }^{23}$

Alarmingly, the United States spends billions of dollars each year to finance its deficit consumption. ${ }^{24}$ The 2010 U.S. Budget's projected expenditures were $\$ 3.8$ trillion, ${ }^{25}$ and the cost to finance that spending was approximately $\$ 1.4$ trillion. ${ }^{26}$ This equates to roughly forty cents borrowed for every dollar spent by the government. ${ }^{27}$ Continued deficit spending at this rate is unsustainable $;^{28}$ it is "like a cancer that will truly destroy th[e] country from within if [it is not fixed]." ${ }^{.29}$ One of many proposed legislative solutions is the enactment of massive spending cuts, ${ }^{30}$ but, even with changes to the nation's entitlement programs, spending cuts will not be sufficient. ${ }^{31}$ The United States government must increase revenue to resolve the country's fiscal problems. ${ }^{32}$

18. See Policy Basics: Where Do Our Federal Tax Dollars Go?, CENTER ON BUDGET \& POL'Y PrIORITIES, http://www.cbpp.org/cms/index.cfm?fa=view\&id=1258 (last updated July 12, 2012).

19. A nation's Gross National Product is defined as " $[\mathrm{t}]$ he monetary value of all the finished goods and services produced within a country's borders in a specific time period." Gross Domestic Product (GDP) Definition, INVESTOPEDLA, http://www.investopedia.com/ terms/g/gdp.asp (last visited Aug. 1, 2012).

20. Brian Riedl, $A$ Guide to Fixing Social Security, Medicare, and Medicaid, HeRITAGE FouND. (Mar. 11, 2008), http://www.heritage.org/research/ reports/2008/03/a-guide-to-fixingsocial-security-medicare-and-medicaid.

21. $I d$.

22. See id.

23. Id.

24. See Joshua Miller, Senator: Deficit Commission Is 'Shock Therapy', ABCNEws (Nov. 14, 2010), http://abcnews.go.com/ThisWeek/senator-deficit-commission-shocktherapy/story?id=12144658.

25. OfFice of Mgmt. \& Budget, Historical Tables: Budget of the United States GOVERNMENT, FISCAL YEAR 2010, at 314 (2009), available at http://www.gpo.gov/ fdsys/pkg/BUDGET-2010-TAB/pdf/BUDGET-2010-TAB.pdf.

26. Id.

27. Miller, supra note 24.

28. Riedl, supra note 20.

29. Andrew Taylor, Commission Leaders Say Cutting Deficit Will Hurt, THE DaILY News (Nov. 12, 2010), http://www.memphisdailynews.com/ editorial/Article.aspx?id=54176.

30. David Rogers, Rand Paul Unveils $\$ 500 B$ in Cuts, Politico (Jan. 25, 2011), http://www.politico.com/news/stories/0111/48178.html.

31. Riedl, supra note 20.

32. See id. 
In order to increase tax revenue, some economists, including several of President Barack Obama's top economic advisors, recommend that the federal government implement a value-added tax (VAT). ${ }^{33}$ A VAT is a "type of consumption tax that is placed on a product whenever value is added at a stage of production and at final sale." ${ }^{34}$ The VAT due on any sale is a percentage of the sales price, but the taxable person is entitled to deduct from this percentage all tax paid at the preceding stage..$^{35}$ Therefore, there is no double taxation; a tax is paid only on the value added at each stage. The VAT is already a popular method for increasing tax revenue in many EU Member Nations. ${ }^{36}$ And with the United States facing unsustainable deficits and a shrinking tax base, there has been renewed support for implementing a VAT from the Obama administration and economists at large. ${ }^{37}$

As a preliminary issue, this Note examines the complicated and disadvantageous corporate tax structure currently employed in the United States. ${ }^{38}$ It then discusses the value-added tax, both in a theoretical sense ${ }^{39}$ and through its practical application in the European Union. ${ }^{40}$ Though the VAT's use is not complicated, the concept is foreign to many Americans. This Note concludes by recommending that the United States: (1) abolish the corporate income tax and replace it with a VAT, and (2) use the increased revenue to pay down the current national debt. ${ }^{41}$ Implementing these recommendations will encourage businesses to locate and remain in the United States, and will incentivize companies not to shift profits overseas to take advantage of lower tax rates. Ultimately, this will keep more tax revenue in the country and will help reduce the national debt.

\section{CURRent United STATES CORPORATE TAX POlicy}

\section{A. Corporate Taxation Under the Internal Revenue Code}

The United States corporate tax system is based on profits. ${ }^{42}$ U.S. corporations are taxed on their worldwide income, ${ }^{43}$ defined as gross income

33. Murphy, supra note 12.

34. Value-Added Tax (VAT) Definition, INVESTOPEDIA, http://www.investopedia.com/ terms/v/valueaddedtax.asp (last visited Aug. 1, 2012).

35. Murphy, supra note 12.

36. $I d$.

37. See id.

38. See infra Part II.

39. See infra Part III.

40. See infra Part IV.

41. See infra Part V.

42. J. ECon. COMm., 105th CONG., Reforming the U.S. Corporate TaX System to INCREASE TAX COMPETITIVENESS 2 (2005).

43. 26 U.S.C. $\$ 11(2010)$. 
minus various tax deductions. ${ }^{44} \mathrm{~A}$ corporation can limit its tax liability by subtracting from its taxable income the corporation's net capital $\operatorname{loss}^{45}$ as well as other deductions, ${ }^{46}$ most notably the business interest deduction. ${ }^{47}$ Corporations can also reduce their tax liability through various credits. ${ }^{48}$ The foreign tax credit is the largest, allowing corporations to deduct "the amount of any income, war profits, and excess profits taxes paid or accrued during the taxable year to any foreign country or to any possession of the United States. ${ }^{, 49}$ In theory, corporate taxation in the United States is simple: a corporation pays a certain percentage of its taxable income to the government. ${ }^{50}$ However, the use of deductions and creative accounting methods complicates this system and allows U.S. companies to lower their tax liability at the expense of the American taxpayer. ${ }^{51}$

\section{B. Results of the Complex Corporate Tax Code}

The United States tax code is "a patchwork of overly complex, inefficient, and unfair provisions that impose large costs on corporate business. ${ }^{52}$ This complexity has created a corporate tax system where corporations make "business decisions based not on what [is] good or bad for their employees, customers, and shareholders, but rather on what would have the best tax implications. ${ }^{, 53}$ Specifically, the U.S. corporate tax system has four "significant flaws":

(1) it provides artificial tax incentives for firms to locate real economic activity and report profits in low-tax countries; (2) it places U.S.-headquartered firms at a competitive disadvantage; (3) it is unworkably complex; and (4) it raises relatively little revenue, even though the U.S. corporate tax rate exceeds that in most other advanced industrial countries. ${ }^{54}$

44. Id. $\S 63$.

45. Id. $\S 1211$.

46. See, e.g., id. $\S \S 243,246,248$.

47. Id. $\S 163$.

48. See generally id. §§ 21-54.

49. Id. $\S 901$.

50. See id. $\S \S 11-12$.

51. Ezra Klein, Our Dumb Corporate Tax System, WASH. Post (Sept. 27, 2010), http://voices.washingtonpost.com/ezra-klein/2010/09/our_dumb_corporate_tax_system.html; see supra notes $15-18$ and accompanying text.

52. J. ECON. COMM., supra note 42, at 1.

53. Neal Boortz \& John Linder, FairTaX: The Truth, at x (2008).

54. Kimberly Clausing, International Taxation: What Are the Options for Reform?, in TAX POLICY BRIEFING BooK, II-15-13 (last updated Oct. 17, 2007), available at 
Unless "tax reforms are enacted[,] it is likely that U.S. tax competitiveness will continue to suffer. The results of inaction are undesirable: potential loss of American jobs, foreign outsourcing of economic content, sale of U.S. companies to foreign multinational firms, and general erosion of the corporate tax base." 55

\section{Incentives to Locate Economic Activity and Report Profits in Low- Tax Countries}

The current U.S. corporate tax system provides artificial incentives for corporations to relocate real economic activity to other countries. ${ }^{56}$ Since 2000 over two million manufacturing jobs have been outsourced from the United States, ${ }^{57}$ and the next wave of outsourcing is expected to come from the whitecollar sector. ${ }^{58}$ Boston-based consulting firm Forrester estimates that about twelve thousand to fifteen thousand service jobs per month have been outsourced since 2000, ${ }^{59}$ and the McKinsey Global Institute predicts a 30 percent to 40 percent increase over the next five years. ${ }^{60}$ Forrester further predicts that "roughly 3.3 million service jobs will have moved offshore" by $2015 .{ }^{61}$ Combined with the recent economic crisis, this outsourcing led to an 8.5 percent unemployment rate in the United States as of January $2012 .{ }^{62}$ This figure must be lowered in order to restore the U.S. economy and reduce the country's national debt. ${ }^{63}$ However, under the current tax framework, the unemployment rate is expected to stay above 6 percent until $2015 .^{64}$

The complex corporate tax system employed in the United States also encourages companies to shift profits to countries with lower corporate tax rates. ${ }^{65}$ For example, in October 2010 it came to light that Google Inc. lowered its tax liability by $\$ 3.1$ billion over the three previous years by shifting overseas profits to Bermuda through Ireland and the Netherlands. ${ }^{66}$ By employing

http://www.taxpolicycenter.org/briefing-book/key-elements/international/reform.cfm (numeration added).

55. J. ECON. COMM., supra note 42, at 1.

56. Id.

57. Liza Porteus, States Tackle Outsourcing, FoxNews.com (Apr. 19, 2004), http://www.foxnews.com/story/0,2933,117432,00.html.

58. Id.

59. Sharon Otterman, TRADE: Outsourcing Jobs, COUNCIL ON FOREIGN REL. (Feb. 20, 2004), http://www.cfr.org/publication/7749/trade.html\#p6.

60. Id.

61. Id.

62. News Release, Bureau of Labor Statistics, U.S. Dep't of Labor, Employment Situation Summary (Jan. 6, 2012).

63. See Sewell Chan, Obama Advisers Predict Unemployment of $8.2 \%$ by 2012, N.Y. TIMES, Feb. 11, 2010, at B3, available at http://www.nytimes.com/2010/ 02/12/ business/economy/12usecon.html.

64. Id.

65. See Clausing, supra note 54.

66. Drucker, supra note 9. 
creative accounting techniques, Google achieved an effective tax rate of 2.4 percent in 2009, while the corporate tax rates of the United States and Great Britain, Google's two largest markets by revenue, were 35 percent and 28 percent, respectively. ${ }^{67}$ "'It's remarkable that Google's effective rate is that low,' said Martin A. Sullivan, a tax economist and former employee of the U.S. Treasury Department. 'We know this company operates throughout the world mostly in high-tax countries where the average corporate rate is well over 20 percent.", 68

Google achieved its reduced tax liabilities primarily through two creative accounting techniques, known as the "Double Irish" and the "Dutch Sandwich." ${ }^{69}$ The Double Irish structure calls for a U.S. corporation to establish two subsidiaries in Ireland ("Sub-1" and "Sub-2"). ${ }^{70}$ Sub-1 is established under Irish law but is controlled and managed from a low-tax nation such as Bermuda. ${ }^{71}$ Sub-2 is owned by Sub- 1 and is controlled from Ireland ${ }^{72}$ Because Ireland determines tax residency from the location of a company's control activities, Sub-1 will be treated as a Bermuda company under Irish tax law. ${ }^{73}$ In contrast, the United States bases tax consequences on a company's jurisdiction of incorporation. ${ }^{74}$ Accordingly, Sub-1 will be treated as an Irish company under U.S. tax law, despite having its control activities in Bermuda. ${ }^{75}$

A hybrid structure is created by Sub-2's election to become a separate entity from Sub-1. ${ }^{76}$ Sub-1 and Sub-2 "will be combined and treated as a single Irish corporation for U.S. federal tax purposes, but will continue to be treated for Irish tax purposes as two distinct corporations-a Bermuda resident corporation and its Irish subsidiary." 77 To complete the Double Irish, Sub-1 "will enter into a cost sharing arrangement with its U.S. parent for the codevelopment of the applicable intellectual property (e.g., the software code).,"78 Sub-1 will license the intellectual property to Sub-2, which will produce

67. Id.

68. Id.

69. 'Double Irish With a Dutch Sandwich', N.Y. TIMES (Apr. 28, 2012), http://www.nytimes.com/interactive/2012/04/28/business/Double-Irish-With-A-Dutch-

Sandwich.html.

70. Joseph Darby III \& Kelsey Lemaster, Double Irish More Than Doubles the Tax Savings: Hybrid Structure Reduces Irish, U.S. and Worldwide Taxation, PRAC. INT'L TAX STRATEGIES, May 15, 2007, at 2, 13, available at http://www.gowlings.com/resources/ PublicationPDFs/Hejazi_Hill_IntTaxMay07.pdf.

71. Id.

72. Id.

73. Id. Under Irish tax law, a company will be treated "as a non-resident if that company (1) 'controls' an Irish company that conducts an active business in Ireland and (2) is 'controlled' by one or more residents of a country with which Ireland has a double taxation treaty." Id.

74. Id.

75. Id.

76. Id.

77. Id.

78. Id. 
software products in Ireland and sell those products in other countries. ${ }^{79}$ This arrangement creates a situation where transactions between Sub-1 and Sub-2 will have no effect under the U.S. corporate tax system. ${ }^{80}$ The United States will disregard the license payments, and Ireland will treat the payments as royalties paid to the Bermuda corporation. ${ }^{81}$ The result is that "little or no tax will be paid on the income earned in Bermuda, and only a 12.5 percent tax will be paid on income earned in Ireland." ${ }^{82}$ The Dutch Sandwich is an additional step in the process that allows companies to further reduce the tax liabilities decreased under the Double Irish strategy. ${ }^{83}$

Google is not the only corporation that uses the Double Irish and Dutch Sandwich to reduce its tax liability. Microsoft Corp., Facebook Inc., Forest Laboratories, and many other technology and pharmaceutical companies have used these techniques as part of their business operations. ${ }^{84}$ Combined, these corporations cost governments much-needed tax revenues. "Companies that use the Double Irish arrangement avoid taxes at home and abroad as the U.S. government struggles to close a projected $\$ 1.4$ trillion budget gap and European Union countries face a collective projected deficit of 868 billion euros. ${ }^{.85}$ The Obama administration and the United States Treasury Department have proposed measures to limit the use of the Double Irish and Dutch Sandwich, but so far, there has been little progress in passing legislation to curb these exotic income-shifting strategies. ${ }^{86}$

\section{The United States Corporate Tax Code Creates Disadvantages for United States-Headquartered Companies}

The current United States tax law "encourages U.S. multinationals to locate assets and economic activity, and earn and realize profit, in other countries where taxes are lower. ${ }^{, 87}$ Companies that locate assets and conduct economic activity within the United States are at a comparative disadvantage to those operating outside the country. ${ }^{88}$ As explained above, companies can save billions of dollars in taxes by shifting income to another country with lower tax

\footnotetext{
79. Id.

80. Id.

81. Id.

82. Id. at 14.

83. Id.

84. Drucker, supra note 9.

85. Id.

86. $I d$.

87. Kimberly Clausing, International Taxation: How Does The Tax System Impact U.S. Competitiveness?, in TAX POLICY BRIEFING BoOK, II-15-8 (last updated Oct. 17, 2007), available at http://www.taxpolicycenter.org/briefing-book/key-elements/international/ competition.cfm.

88. Id.
} 
rates. ${ }^{89}$ These tax strategies also have a great impact on a company's valuation since the company will have more capital to reinvest in business operations. ${ }^{90}$ For example, analysts estimate that without shifting income through the Double Irish and Dutch Sandwich, Google's stock price might be reduced by $\$ 100$ per share. ${ }^{91}$ For companies that do not shift income outside the United States and do not outsource labor, "these undesirable consequences of the tax system may indirectly contribute to weaker U.S. competitiveness." 92

In 2003 the National Association of Manufacturers (NAM) released a report summarizing the important economic factors facing U.S. manufacturers. ${ }^{93}$ Excessive taxation was listed as number one, ranking ahead of the escalating costs of health and pension plans, increasing tort litigation costs, compliance costs for regulatory mandates, and rising energy costs. ${ }^{94} \mathrm{NAM}$ calculated that the U.S. tax system gives foreign companies a 5.6 percent advantage in raw costs compared to domestic companies, ${ }^{95}$ and it recommended that the United States "[r]educe the corporate tax burden and reform the treatment of foreign-source income." 96

\section{The United States Tax Code is Unworkably Complex}

The Internal Revenue Code (IRC) is very long and complex. ${ }^{97}$ Since its enactment in 1913, the IRC has grown from 400 to 67,204 pages, increasing in length by forty-three percent from 2000 to $2006 .{ }^{98}$ Because of the complexity of the IRC and the reporting requirements public companies face, companies must hire accountants and auditors to prepare their taxes and financial statements. Additionally, as a result of corporate scandals in the late 1990 s and early 2000 s, Congress passed the Sarbanes-Oxley Act to "enhance corporate responsibility, enhance financial disclosures and combat corporate and accounting fraud."99 Despite these good intentions, the Sarbanes-Oxley Act has drawn a great deal

89. See supra Part II.B.1.

90. Drucker, supra note 9.

91. Id.

92. Clausing, supra note 87.

93. JeREMY A. LeONARD, NAT'l AsS'N OF MFrs., How Structural Costs IMPOSED ON U.S. MANUFACTURERS HARM WORKERS AND THREATEN COMPETITIVENESS (2003), available at http://www.themanufacturinginstitute.org/ /media/5469DAC833E344E8925AB9681EAEB167. ashx.

94. Id. at 1.

95. Id. at 12.

96. Id. at 3.

97. See americans for Fair Taxation, What the Federal TaX System Is Costing YOU-BEsIDES YOUR TAXES! 2 (2007), available at www.fairtax.org/PDF/ What TheFederalTaxSystemIsCostingYou.pdf.

98. Id.

99. U.S. Sec. \& Exch. Comm'n, The Laws that Govern the Securities Industry, http://www.sec.gov/about/laws.shtml\#sox2002 (last updated June 27, 2012). 
of criticism for the heavy burden it places on companies. ${ }^{100}$

Companies spend a significant amount of money to comply with the Sarbanes-Oxley Act in addition to the cost of filing their taxes. Section 404 of the Act is one of its most "onerous" aspects. ${ }^{101}$ It requires companies to annually produce "an internal control report" that

(1) state[s] the responsibility of management for establishing and maintaining an adequate internal control structure and procedures for financial reporting; and (2) contain[s] an assessment, as of the end of the most recent fiscal year of the issuer, of the effectiveness of the internal control structure and procedures of the issuer for financial reporting. ${ }^{102}$

It is estimated that $\S 404$ costs companies about $\$ 2.3$ million each year in direct compliance costs. ${ }^{103}$ Problematically, the benefits from $\S 404$ do not seem to be worth these costs. ${ }^{104}$ Only nineteen percent of companies surveyed said that the benefits from $\S 404$ outweigh the enormous costs of compliance. ${ }^{105}$ Furthermore, preparing tax returns and complying with other IRC provisions are also expensive for companies. ${ }^{106}$ In 2005 United States companies paid $\$ 147.7$ billion to comply with the IRC, ${ }^{107}$ and these compliance costs are projected to be $\$ 268.9$ billion by 2015 . $^{108}$

The complexities of the IRC have had a negative effect on government revenues from corporate taxes. ${ }^{109}$ Corporate tax receipts have been on a downward trend over the past few decades, as the IRC has become more complex and as more loopholes have become available for corporations to exploit. ${ }^{110}$ During fiscal year 1960 , corporate tax receipts totaled 4.2 percent of GDP, while in 2004 corporate tax receipts totaled only 1.6 percent-a decrease of 2.6 percent. ${ }^{111}$ As the list of companies using tax loopholes gets longer, less and less tax revenue is generated for the United States Treasury.

With a deteriorating fiscal situation in the United States, the government

100. See James Freeman, The Supreme Case Against Sarbanes-Oxley, WaLl ST. J. (Dec. 15, 2009), http://online.wsj.com/article/ SB100014240527487044318045745339921864252380.html.

101. Id.

102. 5 U.S.C. $\S 7262(a)(2010)$.

103. Id.

104. Id.

105. Id.

106. AMERICANS FOR FAIR TAXATION, supra note 97 , at 3.

107. Id. ("Business pays 55.7 percent of [estimated $\$ 265.1$ billion in total] compliance costs (...").

108. Id. ( 55.7 percent of estimated $\$ 482.7$ billion total).

109. J. ECON. COMM., supra note 42, at 6.

110. Id.

111. Drucker, supra note 9. 
has recognized the revenue problem stemming from the complex corporate tax structure and is looking toward the corporate tax system to increase revenues. In his 2011 State of the Union Address, President Obama announced that his administration wanted to close corporate tax loopholes in order to help reduce the corporate tax rate. ${ }^{112}$ "'Those with accountants or lawyers to work the system can end up paying no taxes at all. But all the rest are hit with one of the highest corporate tax rates in the world. It makes no sense. It has to change," the President said. ${ }^{113}$ Recognition of the problem is important; however, the government needs to take action. ${ }^{114}$

\section{The United States Corporate Tax Raises Relatively Little Income}

Although corporations pay taxes, individuals shoulder the ultimate tax burden. ${ }^{115}$ Economist Larry Summers opines, "Although unsophisticated observers focus on the distinction between tax relief for business and for individuals, all taxes are ultimately borne by individuals in their role as labor suppliers, consumers, or suppliers of capital." $" 116$ The United States corporate tax system greatly impacts the allocation of capital investment and is biased against savings and investment in three significant ways. ${ }^{117}$

First, "the U.S. tax system favors non-corporate investment over corporate investment." $" 118$ Under the IRC, companies are subject to complex depreciation rules and inflation adjustments. ${ }^{119}$ Moreover, corporate income distributed to shareholders, usually in the form of dividends, is taxed twice: once when a corporation earns the income and once when dividends are paid to a shareholder. ${ }^{120}$ All other income is taxed only once under the IRC. ${ }^{121}$ This causes corporate income to be taxed more heavily than other sources of income, making the United States less attractive to potential investors. ${ }^{122}$

A numerical example illustrates this disparity. For a corporation in the 35 percent corporate tax bracket, each $\$ 100$ in profit results in $\$ 35$ of federal corporate income tax. ${ }^{123}$ The corporation now has $\$ 65$ of remaining profit either

112. Stephen Ohlemacher, Obama: Lower Corporate Tax Rates, Close Loopholes, BLOOMBERG BUSINESSWEEK (Jan. 26, 2011), http://www.businessweek.com/ ap/financialnews/D9L03HN03.htm.

113. Id.

114. Drucker, supra note 9.

115. J. ECON. COMM., supra note 42, at 9.

116. Id. at 2 .

117. Id. at 4

118. Id.

119. Id. at 5 .

120. Jeffrey L. Kwall, The Uncertain Case Against the Double Taxation of Corporate Income, 68 N.C. L. REV. 613, 614-15 (1990).

121. Id.

122. Id. at 615 .

123. J. ECON. COMM., supra note 42, at 5. 
to re-invest in the corporation or to distribute to shareholders as dividends. ${ }^{124}$ If the corporation distributes the remaining $\$ 65$ profit, the shareholders will be taxed on those dividends at the individual level. ${ }^{125}$ Individuals in the 15 percent dividend tax bracket, the highest current rate, will pay $\$ 9.75$ in dividend taxes on the distribution of the remaining $\$ 65$ profit. ${ }^{126}$ Thus, the effective tax rate of this transaction is 44.75 percent. ${ }^{127}$ This higher tax rate does not include any additional state and local taxes at both the corporate and individual level. ${ }^{128}$ By contrast, most other capital gains from non-corporate investments are taxed only once, at the 15 percent dividend rate. ${ }^{129}$

Double-taxation causes corporate investments to be significantly more expensive than non-corporate investments. ${ }^{130}$ According to the United States Treasury Department, the average tax burden on a new corporate investment is 24 percent, whereas the average tax burden on a new non-corporate investment is 17 percent. ${ }^{131}$ This disparity goes against "the tax policy goals of equality and efficiency." 132 Furthermore, the double-taxation scheme affects business decisions on how much dividends to pay out to shareholders, regardless of what the most efficient use of the money would be. ${ }^{133}$ This potential conflict of interest makes corporate investments even less favorable than non-corporate investments. Changing the corporate tax system could eliminate many of these problems ${ }^{134}$ and level the playing field between corporate and non-corporate investment. ${ }^{135}$

The second way the current U.S. corporate tax system is biased against savings and investment is by favoring corporate debt over corporate equity investment. ${ }^{136}$ This occurs because business interest payments are tax deductible under the IRC. ${ }^{137}$ Further, when corporations take on debt, the corporation only has to pay back the principal of the debt and the interest incurred. ${ }^{138}$ Debt financing allows the owners of the corporation to keep a

124. Id.

125. Id.

126. Id.

127. Id. $((\$ 35+\$ 9.75) / \$ 100)$.

128. Id.

129. Id.

130. N. Gregory Mankiw, Principles of Economics 258 (5th ed. 2008).

131. Id.

132. Kwall, supra note 120.

133. Joseph J. Cordes, Double Taxation of Dividends, in THE ENCYCLOPEDIA OF TAXATION \& TAX POLICY 83 (Joseph J. Cordes et al. eds., 2d ed. 2005).

134. J. ECON. COMM., supra note 42 , at 5.

135. Id. at 12 .

136. Id. at 4 .

137. Id.

138. Debt vs. Equity-Advantages and Disadvantages, FindLaw.com, http://smallbusiness.findlaw.com/banking_financing/bel_Sdebtvsequity.html (last visited Aug. 1, 2012). 
larger portion of the profits of a company because equity financing dilutes the ownership of the corporation. ${ }^{139}$ In recent years, however, equity financing has become relatively more popular by individuals because dividend tax rates are lower and capital gain taxes can be deferred until an individual sells its stock. ${ }^{140}$

The third manifestation of the tax system's bias against savings and investment is that "foreign-owned firms have a competitive tax advantage over domestic firms." "141 "No country has rules for the immediate taxation of foreignsource income that are comparable to the U.S. rules in terms of breadth and complexity," ${ }^{, 142}$ and the U.S. effective corporate tax rate is fifty percent higher than the average of OECD member states. ${ }^{143}$ In response to the increased competitiveness of the global marketplace, U.S. corporations have lowered costs by reducing tax liabilities. ${ }^{144}$ And as capital has moved more freely across international borders, naturally, it has left nations with higher tax rates in favor of those with lower tax rates. ${ }^{145}$ Studies show that profits earned by U.S. corporations in lower-tax jurisdictions outside the United States increased by sixty-four percent in recent years. ${ }^{146}$ This translates to $\$ 33$ billion in profits that could have been taxed by the United States government. ${ }^{147}$

\section{A Call for Change in the Corporate Tax System}

As a result of the IRC's unworkably complex corporate section, ${ }^{148}$ the United States economy has been hindered by high compliance costs and the loss of business overseas. ${ }^{149}$ Not only does the complexity of the U.S. corporate tax system negatively affect domestic business, it generates less money than alternatives could. ${ }^{150}$ Every year, legislation is proposed to change the tax code. ${ }^{151}$ However, a mere changing of the marginal rates or deduction rules will be insufficient to deal with the systematic problem caused by the arcane IRC. To promote efficiency, fairness, and international competitiveness, a complete

139. Id.

140. J. ECON. COMM., supra note 42, at 5-6.

141. Id. at 4.

142. $I d$.

143. Hodge, supra note 1.

144. J. ECON. COMM., supra note 42, at 6.

145. Jeffrey L. Rubinger \& William B. Sherman, Holding Intangibles Offshore May Produce Tangible Tax Benefits, 106 TAX NOTES 938, 938 (2005), available at http://www.lawprofessorblogs.com/taxprof/linkdocs/2005-2977-1.pdf.

146. Id.

147. Id. Intangible assets held outside the United States earned most of these profits. Id.

148. J. ECON. COMM., supra note 42, at 9.

149. Id.

150. See generally id.

151. Federal Tax, DUKE LAw, http://www.law.duke.edu/lib/researchguides/fedtax (last updated Aug. 2011). 
overhaul of the system is needed. ${ }^{152}$ While there have been several proposed IRC overhauls, these bills have not made it very far through the legislative process. ${ }^{153}$

Despite a history of legislative roadblocks, the United States government is once again realizing that tax reform must be enacted. ${ }^{154}$ The poor condition of the country's economy, combined with the negative results and corresponding criticism of its complex IRC, have led the Obama administration to consider overhauling the IRC for the first time since $1986 .{ }^{155}$ The administration hopes an overhaul of the corporate tax system could eliminate the IRC's misguided incentives while lowering the corporate tax rate in an effort to attract more capital to the United States. ${ }^{156}$ According to a senior Obama administration official, "We need to test the true appetite of business for reform that simplifies the system and lowers rates without making the deficit worse." 157

\section{VALUE ADDED TAX}

\section{A. Theory of the Value-Added Tax}

Economists and legislators have proposed many theories and plans for overhauling the corporate tax system (and the United States tax system as a whole); however, this Note argues that any viable proposal should begin with the enactment of a value added tax. "A VAT is a multistage tax imposed on the 'value added' to goods as they proceed through the stages of production and distribution and to services as they are rendered. The 'value added' consists of the four economic factors of production-wages, profit, rent and interest." Importantly, a company is able to offset the tax it already paid against the tax liability that will arise from the company's sale of a good or service. ${ }^{159}$

In levying a VAT, there are four basic forms that can be used: (1) the

152. J. ECON. COMM., supra note 42, at $9,15$.

153. See generally James M. Bickley, Flat Tax Proposals and Fundamental TaX REFORM: AN OVERVIEW (2006), available at www.policyarchive.org/ handle/10207/bitstreams/2840.pdf [hereinafter FLAT TAX PROPOSALS]; see also JAMES M. BICKLEY, A VALUE-ADDED TAX CONTRASTED WITH A NATIONAL SALES TAX (2003), available at http://crs.ncseonline.org/nle/crsreports/03May/IB92069.pdf.

154. See Peter Cohn, Obama Looks to Congress and Vice Versa to Kick Off U.S. Tax Code Overhaul, BLOOMBERG (Feb. 3, 2011), http://www.bloomberg.com/news/ 2011-02-03/obamalooks-to-congress-and-vice-versa-to-kick-off-u-s-tax-code-overhaul.html.

155. Id.; Tim Fernholz, Obama Eyes Corporate Tax Reform, ATlantic (Jan. 24, 2011), http://www.theatlantic.com/politics/archive/2011/01/obama-eyes-corporate-tax-reform/70056/.

156. Fernholz, supra note 155.

157. Id.

158. Alan Schenk, Value Added Tax: Does this Consumption Tax Have a Place in the Federal Tax System?, 7 VA. TAX REV. 207, 225-26 (1987).

159. Llam Ebrill et al., The Modern VAT 1 (2001). 
additive-direct or accounts method, (2) the additive-indirect method, (3) the subtractive-direct or accounts method, and (4) the subtractive-indirect or invoice method ${ }^{160}$ In practice, most countries use the invoice method to collect VAT from businesses. ${ }^{161}$ Under the invoice method, a seller charges the VAT rate on his output and gives a buyer an invoice detailing the amount of tax charged to that product. ${ }^{162}$ This multi-step process has the benefits of helping corporations police themselves, taxing only the value added at each stage of production and distribution, and avoiding double taxation. ${ }^{163}$ "In this way, as the final price of the product is equal to the sum of the values added at each preceding stage, the final VAT paid is made up of the sum of the VAT paid at each stage." $" 164$

While the other three VAT methods are seemingly less complicated, the invoice method is preferred because it attaches the tax liability to the transaction. ${ }^{165}$ It can also accommodate multiple VAT rates, unlike the two additive methods. ${ }^{166}$ Additionally, companies find the invoice method to be more convenient than the month-by-month calculation of value added under the subtractive-direct method, because "purchases, sales, and inventories can fluctuate greatly." ${ }^{, 67}$ Furthermore, "[i]nvoices are an essential part of the VAT system since they constitute the evidence on the basis of which the purchaser can deduct VAT that has been charged to him." ${ }^{, 168}$ This makes the invoice method easier to audit. ${ }^{169}$

\section{B. Example Value-Added Tax Calculation}

The following VAT calculation has been modified from an example provided by the Taxation and Customs Union of the European Commission: ${ }^{170}$

Stage 1: An auto parts supplier sells parts to General Motors. The sale of the parts is worth $\$ 40,000$ to the auto parts supplier and, if the VAT rate is 20 percent, the auto parts supplier charges General Motors $\$ 48,000$. The auto parts supplier should pay $\$ 8,000$ to the government, but, because the auto parts

160. Alan Tait, Value Added Tax: International Practice and Problems 4 (1988).

161. See id.

162. Taxation \& Customs Union, How VAT Works?, EUR. COMM'N, http://ec.europa.eu/taxation_customs/taxation/vat/how_vat_works/index_en.htm (last updated Nov. 11, 2010).

163. Id.

164. Id.

165. TAIT, supra note 160 , at 4-5.

166. Id.

167. Id.

168. Taxation \& Customs Union, VAT Invoicing Rules, EUR. COMM'N, http://ec.europa.eu/taxation_customs/taxation/vat/traders/invoicing_rules/index_en.htm (last updated Feb. 13, 2012).

169. Id.

170. See id. 
supplier purchased $\$ 20,000$ worth of tools and supplies in the same accounting period, including $\$ 3,000 \mathrm{VAT}$, the auto parts supplier is only required to pay $\$ 5,000^{171}$ to the government as a VAT. The government also receives the $\$ 3,000$ paid by the suppliers from whom the auto parts supplier purchased its tools and supplies. As a result of this transaction, the government receives $\$ 8,000$ - the correct amount of VAT the auto parts supplier should owe from the sale of the vehicle.

SUMMARY OF STAGE 1

Parts: $\$ 40,000$

VAT on parts: $\$ 8,000$

VAT on purchases: $\$ 3,000$

Net VAT of supplier: $\$ 5,000$

Stage 2: General Motors has paid $\$ 8,000$ VAT to the auto parts supplier and, say, another $\$ 2,000 \mathrm{VAT}$ on other purchases for seat belts, electronics, etc. So when General Motors sells a vehicle for $\$ 80,000$, it charges $\$ 96,000$ including $\$ 16,000$ VAT. General Motors deducts the $\$ 10,000$ already paid on its inputs and pays $\$ 6,000$ to the government. The government receives this $\$ 6,000$ from General Motors, $\$ 5,000$ from the auto parts supplier, $\$ 3,000$ paid by the supplier of tools, and $\$ 2,000$ paid by additional suppliers (seat belts, electronics, etc.) to General Motors.

SUMMARY OF STAGE 2

Vehicle: $\$ 80,000$

VAT on vehicle: $\$ 16,000$

VAT on purchases: $\$ 10,000$

Net VAT to be paid: $\$ 6,000$

$\$ 6,000$ (paid by General Motors) $+\$ 5,000$ (paid auto parts supplier) + $\$ 3,000$ (paid by the suppliers to the auto parts supplier) $+\$ 2,000$ (paid by the other suppliers to General Motors) $=\$ 16,000$, or the correct amount of VAT on a sale worth $\$ 80,000$. 


\section{HISTORICAL BACKGROUND AND MODERN POLICY OF THE VAT}

\section{A. European VAT History}

The VAT is a relatively modern tax; it was first discussed in academic settings in the early twentieth century. ${ }^{172}$ "After World War II, progressive income taxes became widespread. During this period, general consumption taxes, especially in Europe, tended to be cascading turnover taxes that were levied at each stage of production and distribution." ${ }^{173}$ While some countries enacted variations of the VAT before the $1960 \mathrm{~s}$, its widespread use emerged during that decade. ${ }^{174}$

The modern European Union developed from the European Economic Community (EEC), which was founded by the Treaty of Rome in $1957 .{ }^{175}$ This Treaty set out a political vision to eliminate "the barriers which divide Europe" and based that vision heavily on economic co-operation between Member States. ${ }^{176}$ The Treaty of Rome made it easier for capital, people, and ideas to move between Members, ${ }^{177}$ and this was achieved in part by providing incentives for the harmonization of business taxes. ${ }^{178}$ Without harmonization, it would have been difficult for the Member States to achieve economic cooperation and to take advantage of the ECC. ${ }^{179}$

In 1962 the ECC's Fiscal and Financial Committee issued the Neumark Report, a study of how the "tax systems of the Member States conflicted with the establishment of a common market." 180 The Report was influential in the eventual harmonization of ECC tax policy, ${ }^{181}$ primarily because of its recommended adoption of the VAT as the Community's sales tax. ${ }^{182}$ For harmonization to work, ECC Member States had to adopt a VAT and abandon, "for intra-Community transactions, the taxation of products in the country of destination in favour of taxation in the country of origin, since this would help

172. EBRILL ET AL., supra note 159, at 4.

173. Alan Schenk, The Plethora of Consumption Tax Proposals: Putting the Value Added Tax, Flat Tax, Retail Sales Tax, and USA Tax into Perspective, 33 SAN DIEGO L. REV. 1281, 1292 (1996).

174. EBRILL ET AL., supra note 159, at 4-5.

175. Treaty of Rome, CIVITAS.ORG, http://www.civitas.org.uk/eufacts/FSTREAT/TR1.htm (last updated July 27, 2011).

176. Id.

177. Id.

178. INT'L VAT ASS'N, COMBATING VAT FRAUD IN THE EU: THE WAY FORWARD 11 (2007),

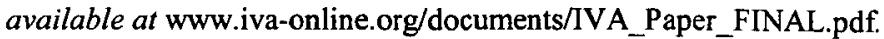

179. See id.

180. B. J. M. Terra \& Peter Jacob Wattel, European Tax Law 122 (2008).

181. PETER RoBSON, THE ECONOMICS OF INTERNATIONAL INTEGRATION 181 (4th ed. 1998).

182. Id. 
abolish tax barriers without distorting competition." ${ }^{183}$ With the Report as its foundation, the European Community ushered the VAT into the mainstream by adopting the first two VAT Directives on April 11, 1967. ${ }^{184}$ These Directives "establish[ed] a general, multi-stage but non-cumulative turnover tax to replace all other turnover taxes in the Member States." 185 They also outlined a general structure for the VAT system and allowed Community Members to determine the rate and coverage of the tax. ${ }^{186}$ The VAT, however, did not become uniform in the European Community until the enactment of the Sixth VAT Directive on May $17,1977 .{ }^{187}$

The Sixth VAT Directive of 1977 standardized the VAT's application between EU Member Nations, but it was not until the 1985 Single European Act that the internal EU market was completed. ${ }^{188}$ The Single European Act allowed people to cross between EU Member States with any amount of taxpaid goods. ${ }^{189}$ Then, to further "limit tax competition and the revenue losses associated with cross-border shopping, [another] significant move toward rate harmonization ... [was] accepted." "190 On January 1, 1993, EU Member States agreed to a standard VAT rate of 15 percent, with some limited exceptions. ${ }^{191}$ This standard rate was imposed to abolish tax frontiers and further promote harmonization between Member States. ${ }^{192}$ This Sixth VAT Directive was amended many times prior its repeal on January $1,2007^{193}$ and its replacement by Council Directive 2006/112/EC ${ }^{194}$ This Directive harmonized various VAT provisions into one source with the intent to "eliminate, as far as possible, factors which may distort conditions of competition" between European Union member nations. ${ }^{195}$

\section{B. European VAT Policy}

The VAT Directives codify the VAT rules that EU Member States must follow. ${ }^{196}$ The EU VAT applies to goods and services bought within the EU

183. INT'L VAT ASs'N, supra note 178, at 11.

184. Id.; History of VAT in the EU, EXPORTVAT, http://www.exportvat.com/ vat_info/vat_eu.htm (last visited July 31, 2012).

185. Id.

186. Id.

187. Id.

188. INT'L VAT Ass'N, supra note 178 , at 12.

189. RoBSON, supra note 181 , at 183.

190. Id.

191. Id.

192. INT'L VAT ASs'N, supra note 178, at 12.

193. Taxation \& Customs Union, supra note 162.

194. Id.

195. Id.; Council Directive 2006/112, whereas 4, 2006 O.J. (L 347) 1 (EC).

196. Ina Dimireva, Common system of VAT (the 'VAT Directive'), EUBUSINESS (Dec. 21, 2009), http://www.eubusiness.com/topics/finance/vat-directive. 
and "is calculated on the basis of the value added to goods and services at each stage of production and of the distribution chain."197 According to the Directives, a taxable person is one "who, independently, carries out in any place any economic activity, whatever the purpose or results of that activity."198 Economic activity includes the production of any goods and services. ${ }^{199}$ When the good is sold or the service is rendered, a chargeable event triggering a VAT takes place. ${ }^{200}$ There are a number of specified exceptions where a transaction is not a chargeable event. ${ }^{201}$

When goods are sold or services are rendered, the taxable amount "includes everything which constitutes consideration obtained by the supplier for transactions by the customer."202 This includes subsidies linked to the transaction and all applicable taxes. ${ }^{203}$ Although the standard European VAT rate is 15 percent, Member States are permitted to apply one or two reduced rates. ${ }^{204}$ The EU, however, has set a 5 percent floor on these reductions. ${ }^{205}$ In addition, some goods and services are exempt from taxation and are sold or rendered to the customer with no added VAT. ${ }^{206}$ These include "certain activities of general interest (such as hospital and medical care, goods and services linked to welfare and social security work, school and university education and certain cultural services or the provision of foodstuffs). "[C]ertain transactions including insurance, the granting of credit, certain banking services, supplies of postage stamps, lotteries and gambling and certain supplies of immovable property" are also exempt. ${ }^{208}$ When these goods or services are sold or rendered, the supplier cannot deduct the VAT on the purchases as it normally could. ${ }^{209}$

Under the VAT system, businesses are tax collectors, not tax payers. ${ }^{210}$ Businesses need to "pay over VAT collected from customers and get a refund of any VAT paid to vendors or on imports."211 When businesses do pay a VAT, the VAT should be recoverable if the business follows the proper procedures. ${ }^{212}$

\footnotetext{
197. Id.; see supra Part III.B (example VAT calculation).

198. Dimireva, supra note 196.

199. Id.

200. Id

201. Id.

202. Id.

203. Id.

204. Id.

205. Id

206. Id.

207. Id.

208. Id.

209. Id.

210. Roger Bevan, VAT in Europe: 7 Steps to Success, EWEEK (Jan. 4, 2008), $\mathrm{http} / /$ www.eweek.com/c/a/IT-Management/VAT-in-Europe-7-Steps-to-Success/.

211. Id.

212. Id.
} 
Unfortunately, like many tax procedures, the VAT rules can be complex if a business is unfamiliar with them. ${ }^{213}$ There also are severe penalties under the European VAT system for noncompliance. ${ }^{214}$ To avoid non-compliance, all businesses dealing in Europe should get a VAT registration, which gives businesses European VAT privileges and makes recordkeeping easier. ${ }^{215}$ Still, it is important for businesses to know local VAT rules as well as the common VAT rules among Member States. ${ }^{216}$ Staying informed about the changes in VAT rules can save companies money from penalties and unclaimed refunds. ${ }^{217}$

European Union Member States are able to generate substantial revenue with the VAT, but the VAT also has presented Members with many challenges. ${ }^{218}$ First, the VAT has become a vehicle of greater public spending for Member States. ${ }^{219}$ When the VAT first appeared in Europe in the 1960s, average government spending was about 30.2 percent of GDP. ${ }^{220}$ Today, European Union Member States spend on average 47.1 percent. ${ }^{221}$ In that same time period, the United States government spending rose from 28.3 percent to 35.3 percent. ${ }^{222}$ Additionally, average deficits have been higher in the European Union than in the United States since $1980 .{ }^{223}$ The increased debt and government spending has resulted in less job creation and lower levels of income for Europe. ${ }^{224}$ Over the last two decades, the U.S. economy grew onethird faster than that of the European Union Member States. ${ }^{225}$ Finally, European Union Member States have struggled with VAT fraud, ${ }^{226}$ resulting in an estimated loss of $€ 60-€ 100$ billion per year. ${ }^{227}$

\section{United States VAT History}

The VAT has been present in American political discourse since the

213. See id.

214. Id.

215. Id.

216. Id.

217. Id.

218. Shawn Tully, $A$ European-style tax?, CNNMONEY (Dec. 2, 2008), http://money.cnn.com/2008/12/01/news/economy/tully_vat.fortune/index.htm.

219. Editorial, Europe's VAT Lessons, WALL St. J. (Apr. 15, 2010), http://online.wsj.com/ article/SB10001424052702304198004575172190620528592.html.

220. Id.

221. Id.

222. Id.

223. Id.

224. Id.

225. Id.

226. See INT'L VAT Ass'N, supra note 178, at 4.

227. Id. 
1920 s. ${ }^{228}$ Thomas Adams, a prominent U.S. tax economist in the early $1900 \mathrm{~s}$, first introduced the VAT to the United States when he proposed its implementation as a replacement for existing corporate taxes. ${ }^{229}$ At the time, business taxes had "grown up in ad hoc fashion as a response to political pressure and fiscal necessity." ${ }^{, 230}$ Struggling to rationalize these taxes, many leaders pressured their repeal at both the state and national level. ${ }^{231}$ Adams, however, argued that business taxes were "morally necessary":

Surveyed from one point of view, business ought to be taxed because it costs money to maintain a market and those costs should in some way be distributed over all the beneficiaries of that market. Looking at the same question from another viewpoint, a market is a valuable asset to the social group which maintains it and communities ought to charge for the use of community assets. ${ }^{232}$

Initially, Adams thought a net income tax would be easier to implement and more politically acceptable. ${ }^{233}$ But as the tax laws became increasingly complex, Adams began promoting an early form of the VAT because of its simplicity. ${ }^{234}$

Adams's VAT proposal had no impact on state or national tax policy, but it did spark scholarly interest. ${ }^{235}$ The VAT continued to be a favorite policy topic among economists ${ }^{236}$ and remained on the fringes of United States tax policy discourse until the 1970 s. $^{237}$ President Richard Nixon considered a VAT proposal during his term in office, but he and other conservatives were concerned by its ability to raise revenue efficiently. ${ }^{238}$ They feared that this could too easily expand the government's power and ability to grow--ideals with which conservatives traditionally disagree. ${ }^{239}$

Various VAT tax proposals have been introduced to Congress during the

228. Joseph J. Thorndike, Early Proposals for an American VAT, TAX ANALYSTS (June 30, 2009), http://www,taxhistory.org/thp/readings,nsf/ArtWeb/ 6F4B8EADA426FDCE852575F600464B81?OpenDocument.

229. Id.

230. Id.

231. Id.

232. Id. (quoting Thomas S. Adams, The Taxation of Business, 1917 PROC. NAT'L TAX Ass'N 185, 187).

233. Id.

234. Id

235. Id

236. Id.

237. Bruce Bartlett, VAT Time?, ForBes.COM (June 5, 2009), http://www.forbes.com/ 2009/06/04/value-added-tax-opinions-columnists-bartlett.html.

238. Id.

239. Id. 
past decade. ${ }^{240}$ The most prominent was the Tax Simplification Act, ${ }^{241}$ which Senator Richard Shelby referred to the Senate Finance Committee in $2005{ }^{242}$ Senator Shelby's bill was influenced by the 1981 VAT proposal by scholars Robert Hall and Alan Rabushka ${ }^{243}$ and was

essentially a modified VAT, with wages and pensions subtracted from the VAT base and taxed at the individual level. Under this proposal, some wage income would not be included in the tax base because of deductions, while under a VAT all wage income would be included in the tax base. ${ }^{244}$

Initially the individual wage tax would be levied at a 19[ percent] rate, but when the tax was fully phased in, this rate would decline to 17 [ percent]. The individual wage tax would be levied on all wages, salaries, pensions, and unemployment compensation. In addition, government employees and employees of nonprofit organizations would have to add to their wage tax base the imputed value of their fringe benefits. ${ }^{245}$

Representative Phil English made a similar proposal in $2006,{ }^{246}$ under which a cash-flow business tax, a VAT variation, could replace the corporate income tax, and the individual income tax would be repealed in favor of a consumption tax. ${ }^{247}$ These plans did not gain much traction in Congress and ultimately failed. ${ }^{248}$ Tax reform was subsequently neglected from 2007 to 2010 , as the United States government focused on saving the U.S. economy and reforming the country's healthcare system. ${ }^{249}$

The 112th Congress, led by a newly elected Republican majority in the House of Representatives, considered one new tax proposal ${ }^{250}$ submitted by Representative Paul Ryan. ${ }^{251}$ Representative Ryan's plan replaces the corporate

240. See generally FLAT TAX PROPOSALS, supra note 153.

241. Tax Simplification Act of 2005, S. 1099, 109th Cong. (2005).

242. Flat TAX Proposals, supra note 153, at 5-6.

243. Id.; see generally William Gale, Flat Tax, in THE ENCYCLOPEDIA OF TAXATION \& TAX PouICY 155 (Joseph J. Cordes et al. eds., 1st ed. 1999), available at www.urban.org/ uploadedPDF/1000530.pdf.

244. Flat TAX Proposals, supra note 153, at 6.

245. Id.

246. The Simplified USA Tax Act of 2006, H.R. 4707, 109th Cong. (2006).

247. Flat TAX Proposals, supra note 153, at 7.

248. Id.

249. Id.

250. Roadmap for America's Future Act of 2010, H.R. 4529, 11 lth Cong. (2010).

251. JAMES M. BICKLEY, TAX REFORM: AN OVERVIEW OF PROPOSALS IN THE 112TH CONGRESS 6 (2011). 
tax with a subtraction-method VAT referred to as a "Business Consumption Tax" (BCT) ${ }^{252}$ The BCT would be 8.5 percent and would have a broad base, which is much lower than the current 35 percent corporate rate. ${ }^{253}$ Under the Ryan Plan, individual taxes would still be levied on income, but the system would be simplified. ${ }^{254}$

\section{United States VAT Policy}

\section{Benefits of the Value-Added Tax}

While Republicans and Democrats differ in their opinions of what constitutes an ideal tax system, members in both parties agree that the current tax system needs changing. The IRC encompasses several types of taxes, ${ }^{255}$ but this Note focuses on changes the United States corporate tax. As both parties determine what corporate tax system best fits the U.S. economy, ${ }^{256}$ they should look to the VAT as a solution to the murky corporate tax code.

Implementing a VAT will improve the United States' competitive position in the international marketplace. ${ }^{257}$ According to Procter \& Gamble CEO Robert McDonald, "[i]f [U.S. companies] are handicapped by an uncompetitive corporate tax system, [it] will slow the growth of the U.S. economy to the benefit of our competitors. ${ }^{258}$ In the short term, assuming that the VAT is at a lower rate than the current 35 percent corporate tax rate, American products would become cheaper and, thus, more desirable to consumers around the world. ${ }^{259}$ Additionally, a lower corporate tax rate will entice businesses to relocate to the United States and discourage current U.S. companies from relocating or from using exotic accounting methods to avoid paying a relatively higher corporate tax. ${ }^{260}$ Furthermore, the United States had a trade deficit of $\$ 38.3$ billion in November $2010 .{ }^{261}$ Implementing a VAT would likely lower the deficit and create positive effects on international competition.

Implementing a VAT would also greatly simplify the U.S. corporate tax system. ${ }^{262}$ Tax systems are evaluated by their efficiency, equity, and

252. Id. at 7 .

253. Id.

254. Id.

255. See generally 26 U.S.C. $\S 11$ (2010).

256. See Cohn, supra note 154.

257. Schenk, supra note 173, at 1285-86.

258. P\&G, Big U.S. Firms Seek Lower Corporate Rate, Fox Business (Jan. 20, 2011), http://www.foxbusiness.com/markets/201 1/01/20/pg-big-firms-seek-lower-corporate-rate/.

259. See Schenk, supra note 173 , at 1323.

260. See Drucker, supra note 9.

261. Sara Murray, U.S. Trade Deficit Narrows, WALL ST. J. (Jan. 14, 2011), http://online.wsj.com/article/SB $10001424052748703583404576079600579354700 . h t m l$.

262. J. ECON. COMM., supra note 42, at 5. 
simplicity, ${ }^{263}$ and the current United States corporate tax policy is not simple. ${ }^{264}$ Under a VAT system, "complex depreciation rules, inflation adjustments and the allocation of undistributed corporate income would disappear since all forms of saving are removed from the tax base under a consumption-based income tax system., ${ }^{265}$ Furthermore, because the VAT rate would be lower than the current 35 percent corporate rate, companies would have less of an incentive to spend money hiring accountants and lawyers to comply with the tax code and to find tax loopholes in order to lower their tax liabilities. ${ }^{266}$ This would help companies manage the $\$ 268.9$ billion in compliance costs projected for $2015^{267}$

Another benefit of a VAT system would be increased revenue for the United States Treasury. ${ }^{268}$ " [A] U.S. VAT could realistically tax about a third of the gross domestic product (GDP), which would raise close to $\$ 50$ billion per percentage point. If [the United States] adopted Europe's average VAT rate of 20 [ percent, the Treasury] could raise $\$ 1$ trillion per year in 2009 dollars." ${ }^{, 269}$ Other studies show that implementing a VAT would result in a net tax revenue increase of $\$ 258.6$ billion over the current tax system. ${ }^{270}$ That extra revenue could be used to help close the current budget deficit and eventually pay down the heavy national debt. Furthermore, implementing a VAT would increase economic output in the United States. ${ }^{271}$ If a VAT were implemented, studies show that the United States economic output would increase between two and four percent. ${ }^{272}$ In the long run, implementing a VAT would raise economic output in the United States an estimated four to six percent. ${ }^{273}$ Raising economic output would increase the tax base, which would result in more tax revenues for the United States government.

\section{Criticisms of the Value-Added Tax}

Although the VAT would simplify the IRC and generate more revenue for the United States government, it is not a perfect tax system. It is commonly

263. Id. at 9 .

264. AMERICANS FOR FAIR TAXATION, supra note 97 , at 2.

265. Id.

266. See id. at 1.

267. See supra note 116 and accompanying text.

268. Bruce Bartlett, Support the VAT, FORBES.COM (Oct. 10, 2009), http://www.forbes.com/ 2009/10/22/republicans-value-added-tax-opinions-columnists-bruce-bartlett.html.

269. Id.

270. ERIC TODER \& JOSEPH ROSENBERG, TAX POLICY CTR., EFFECTS OF IMPOSING A VALUEADDED TAX TO REPLACE PAYROLl TAXES OR CORPORATE TAXES 13, tbl.6 (2010), available at http://www.taxpolicycenter.org/UploadedPDF/412062_VAT.pdf.

271. Gale, supra note 243, at 156.

272. Id.

273. Id. 
criticized as a regressive tax, ${ }^{274}$ "'tak[ing] a larger percentage from low-income people than from high-income people."275 Currently, the United States tax system is progressive, meaning that high-income people and businesses pay a larger percentage of the tax than low-income people and businesses. ${ }^{276}$ Switching from a progressive tax system to a regressive tax system would change the balance of equities currently in place. ${ }^{277}$ Changing to a regressive tax system would likely have substantial political ramifications because fortyseven percent of tax filers do not pay federal income tax. ${ }^{278}$ Washington politicians, Democrats and Republicans alike, will be hesitant to implement a tax system that will make them vulnerable in the next election. ${ }^{279}$

Historically, the VAT has been very unpopular, and foreign leaders who have enacted it experienced a backlash from their citizens. ${ }^{280}$ Most notably, Japanese Prime Minister Yasuhiro Nakasone was defeated in his 1986 reelection bid months after he successfully implemented a VAT. ${ }^{281}$ The 1993 electoral defeat of Canadian Prime Minister Brian Mulroney is also credited to his passage of a VAT in 1991. "Since the poor consume a higher percentage of their income than the well-to-do, they are necessarily going to pay more VAT as a percentage of their income than the well-to-do. There just isn't any getting around that fact."283

The VAT is also criticized because its tax rate can be easily raised. ${ }^{284}$ Proponents of small government are concerned by the ease with which revenue with a low dead-weight cost can be raised under a VAT system. ${ }^{285}$ These critics argue that taxes will be easy to increase if they are insufficiently burdensome and that, to incentivize economic growth, rates need to be easily kept in check. ${ }^{286}$ Because many nations that have enacted a VAT continue to have budget deficits, ${ }^{287}$ this argument has credence. "The deficits that remain year after year would lead to continuous calls for even higher taxes, which would

274. Bruce Bartlett, The Case Against the VAT, ForBes.COM (Apr. 23, 2010), http://www.forbes.com/2010/04/22/vat-taxes-economy-opinions-columnists-bruce-bartlett.html.

275. Regressive Tax Definition, INVESTOPEDIA, http://www.investopedia.com/terms/ r/regressivetax.asp\#axzz1 mHb26Ari (last visited Aug. 1, 2012).

276. Progressive Tax Definition, INVESTOPEDIA, http://www.investopedia.com/terms /p/progressivetax.asp\#axzz1 mHb26Ari (last visited Aug. 1, 2012).

277. Bartlett, supra note 274.

278. Id.

279. See id.

280. Bartlett, supra note 237.

281. Id.

282. Id.

283. Bartlett, supra note 274.

284. Id.

285. Id.

286. Id.

287. Curtis S. Dubay, Value-Added TaX: No Easy FiX for the Deficit 1 (2010), available at http://www.heritage.org/research/reports/2010/01/value-added-tax-no-easy-fix-forthe-deficit. 
lead to more fraud and bigger deficits., ${ }^{288}$ However, the fact that the VAT can easily raise revenue alone should not prevent its enactment. "Congress should end this cycle by simply restraining spending to historical levels and scrapping higher taxes, including the VAT."

Taxpayer fraud is another problem faced by nations that have enacted a VAT. ${ }^{290}$ Theoretically, the VAT is designed as a self-policing tax. ${ }^{291}$ Because the total tax the government ultimately collects is the same, businesses have an incentive to make sure the previous businesses pay the correct tax so they do not get stuck with a higher tax bill. ${ }^{292}$ However, fraud still persists. ${ }^{293}$ In the European Union, Member states lose an estimated $€ 60-€ 100$ billion per year due to fraud, primarily arising from the black economy, insolvencies, and missing traders. ${ }^{294}$

The black economy represents economic transactions that occur with cash and go unreported. ${ }^{295}$ Accordingly, tax revenue is not collected on these transactions. ${ }^{296}$ The black economy accounts for up to thirty percent of GDP in some EU Member States, and some studies show that enacting a VAT will drive more activities underground ${ }^{297}$ Another source of fraud, insolvencies, results when a "supplier of the goods/services never accounts for the tax he has collected from his customer (due to his insolvency) and which the VAT identified customer then recovers. ${ }^{298}$ Missing transfer fraud occurs when "taxpayer A charges VAT to taxpayer B and A never accounts for the VAT paid to it by B. B recovers the VAT paid to A on its VAT return." 299 Other types of fraud exist as well, including invalid deductions of input tax and nonpayment of output tax. ${ }^{300}$ These frauds will cost the United States money and could possibly lead to increased budget deficits. ${ }^{301}$

Opponents of the VAT are also quick to point out that nations that have enacted the tax continue to have budget deficits. ${ }^{302}$ "If it passed a VAT, Congress would undoubtedly budget based on the expectation of receiving all the revenue it anticipates the tax raising. ${ }^{303}$ However, it is unrealistic that the

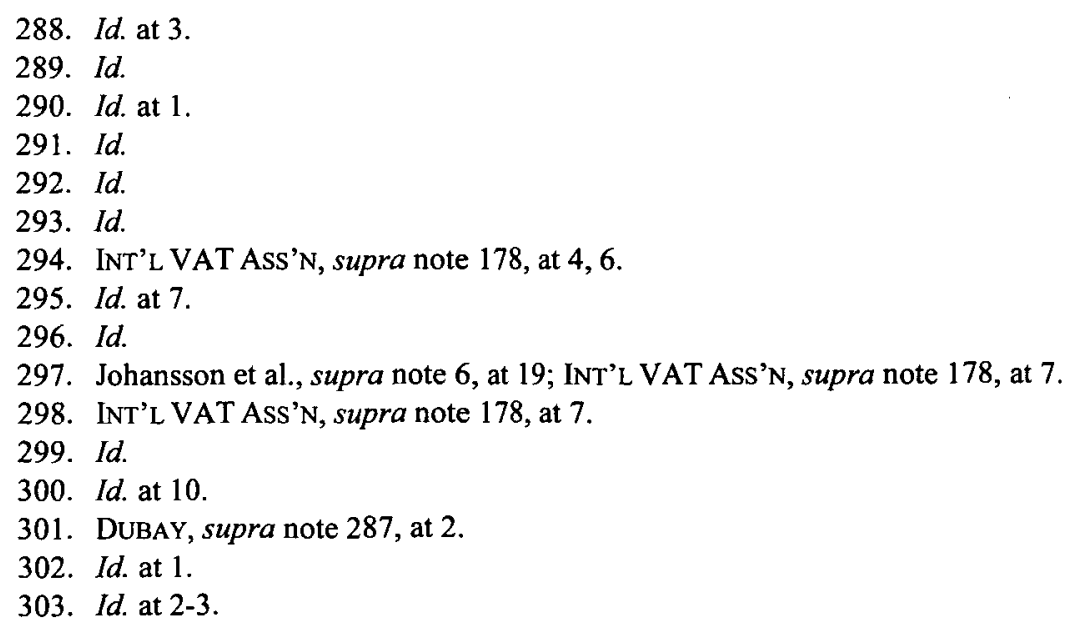


government will be able to collect all the money that is budgeted. ${ }^{304}$ According to the Heritage Foundation, "When the revenue comes in short, as it surely would, the deficit would increase by the amount of the gap, and a substantial deficit would persist. ${ }^{305}$ Although the average annual revenue shortfall of all Member States is 12 percent, some EU Members have a shortfall of up to 30 percent. ${ }^{306}$ By contrast, in 2005 the United States had a twelve percent revenue shortfall. ${ }^{307}$

Many supporters of a VAT in the United States propose a 20 percent rate. ${ }^{308}$ Applying this VAT to the 2005 U.S. tax information, the United States would have generated $\$ 1.26$ trillion in tax revenues, which would be a fifty percent tax increase for that year. ${ }^{309}$ However, using the shortfall data from the European Union, the United States would have had a tax receipt shortfall of $\$ 156$ billion (under the European Union average) and $\$ 390$ billion (the percent amount that many nations faced). ${ }^{310}$ "Annual shortfalls of these magnitudes would prevent a VAT from eliminating the deficit and lowering the debt."311 Furthermore, it takes a country several years to enforce properly the VAT after implementing the new system. ${ }^{312}$

\section{RECOMMENDATIONS}

Although time has distanced the United States from the 2008-2009 recession, the country's economy continues to struggle, ${ }^{313}$ and the job market is still lagging behind the technical recovery ${ }^{314}$ Overhauling the complex United States corporate tax system along with increasing the fiscal responsibility of Congress will help the United States close the projected budget deficits and begin repaying the national debt. This Note recommends that the United States should look to the European Union VAT as a template for the new system, but with certain improvements to better promote economic growth and development.

304. Id. at 3 .

305. Id.

306. Id. at 2 .

307. Id.

308. Id.

309. Id.

310. $1 d$.

311. Id.

312. See Reckon LLP, StUdy to QUANTIFY AND ANALYSE THE VAT GAP IN THE EU-25 MEMBER STATES (2009), available at http://ec.europa.eu/taxation_customs/resources/ documents/taxation/tax_cooperation/ combating_tax_fraud/reckon_report_sep2009.pdf.

313. Don Lee, Recession's Over, Economists Say to a Skeptical Public, L.A. Times (Sept. 21, 2010), http://articles.latimes.com/2010/sep/21/business/la-fi-recession-over-20100921.

314. Jijo Jacob, Top Five Reasons for High Unemployment in US, INT'L BUS. TimES (Feb. 9 , 2011), http://www.ibtimes.com/articles/1 10575/20110209/us-jobs-unemployment-top-fivereasons.htm. 
The first measure in this Note's proposed system is to abolish the corporate income tax. Practically, the United States government cannot tax a corporation-it can only tax individuals. ${ }^{315}$ And although a corporate tax is levied against corporations, ultimately all the money from a corporation ends up going to a person. ${ }^{316}$ However, the current United States corporate tax structure incentivizes companies to spend money to avoid taxes, which provides little economic benefit to the nation as a whole. ${ }^{317}$ Under a VAT structure, compliance costs will be lower than the money companies currently spend to exploit loopholes in the IRC and to comply with the Sarbanes-Oxley Act. ${ }^{318}$ Further, abolishing this high corporate tax rate would make the United States a more attractive place to conduct business. If more businesses and capital come to the United States, job creation would most certainly improve, further stimulating the economy.

This Note proposes a VAT system that shares many of the same characteristics as the tax overhaul plan Representative Paul Ryan has submitted to the 112th Congress. ${ }^{319}$ First, the corporate tax would be abolished and replaced with a subtraction-method VAT or Business Consumption Tax. ${ }^{320}$ Instead of an 8.5 percent VAT under the Ryan plan, however, the proposed VAT would follow the European Union's 15 percent VAT. This Note's proposed VAT system also would be broad-based, "includ[ing] all domestic consumption, except for education, government-financed health care ... services of charitable organizations, and services performed by sub-national governments." ${ }^{321}$ Imposing a broad-based VAT and eliminating the corporate tax would increase tax liability by about $\$ 600$ billion, which represents 3.7 percent of United States GDP. ${ }^{322}$

Enacting a VAT will likely be politically unpopular, especially in the early stages of implementation. ${ }^{323}$ But every tax policy needs to consider equity, efficiency, and simplicity. ${ }^{324}$ Implementing a VAT will be more efficient, both in collection and economic terms, and will be simpler. Moreover, the VAT will be equally administered, whereas both the current income tax and corporate tax systems are progressive. However, there will be a great deal of backlash from citizens because the effective individual tax rate will increase because the price

315. Megan McArdle, Why We Should Eliminate the Corporate Income Tax, ATLANTIC (Oct. 28,2010 ), http://www.theatlantic.com/business/archive/2010/10/why-we-should-eliminate-thecorporate-income-tax $/ 65351 \%$.

316. Id.

317. Id.

318. See supra Part II.B (discussing corporate loopholes and compliance costs).

319. See supra Part IV.C (discussing Rep. Paul Ryan's proposal to Congress).

320. BICKLEY, supra note 251 , at 7 ; see supra note 202 and accompanying text.

321. TODER \& ROSENBERG, supra note 270 , at 12.

322. See id.

323. See supra Part IV.D.2. (discussing political fallout in countries that have enacted a VAT).

324. J. ECON. Comm., supra note 42, at 9. 
of goods and services will increase. While some of this effective tax rate increase will be mitigated with a lowering of the personal income tax ${ }^{325}$ it is likely that individuals will experience a higher tax burden than they currently have. This is especially true for the forty-seven percent of American households that do not pay federal income taxes. ${ }^{326}$ However, this effective increase is necessary if the United States is going to pay down its national debt to a sustainable level.

Congress and the President will need to thoroughly outline how a VAT will increase tax revenues in order to pay down the nation's unsustainable debt. The government also will need to make a serious effort to reign in government spending, including reforming and improving the nation's entitlement programs. With more revenue coming into the United States Treasury Department, the government will be tempted to use the money to increase spending to provide more "benefits" to the public. Many analysts say the European VAT has been a failure because European countries continue to run major deficits. ${ }^{327}$ The European deficit problem is a result of too much spending, not a lack of revenue. ${ }^{328}$ To combat this inherent temptation, Congress should pass a law earmarking a certain percentage of the increased tax revenue for paying down the nation's outstanding debt. The government can further make the VAT plan appealing to the American public by explaining how lower corporate taxes should result in increased capital inflow to the nation, which in turn would create new jobs. Finally, Congress should pledge not to raise the VAT rate from 15 percent and pledge to lower the VAT to 7.5 percent once spending and debt are down to sustainable levels.

\section{CONCLUSION}

Most Americans have felt the effects of the financial crisis and recent economic woes of the United States. While the past two years have been difficult for the nation, things will only get worse if the government does not become financially solvent and lower the national debt. The United States is racking on debt to the point where soon the debt load will greatly hinder the nation's ability to achieve maximum economic output. A lower economic output will only accelerate the nation's financial problem in a never-ending cycle unless the government takes action. While many economists agree that a complete overhaul of the tax system would be best, ${ }^{329}$ it is not politically feasible to enact such an overhaul overnight. "This is more like a warm-up drill,

325. See BICKLEY, supra note 251 , at 7.

326. David Leonhardt, Yes, $47 \%$ of Households Owe No Taxes. Look Closer, N.Y. TIMES (Apr. 13, 2010), http://www.nytimes.com/2010/04/14/business/economy/ 14leonhardt.html.

327. Europe's VAT Lessons, supra note 219.

328. Id.

329. Kim Dixon, Panel Offers Obama Ideas on U.S. Tax Overhaul, ReuTERS (Aug. 27, 2010), http://www.reuters.com/article/idUSTRE67Q5GH20100827. 
not the game itself," said William Gale, co-director of the Tax Policy Center, a think tank located in Washington, D.C. ${ }^{330}$ "Congress has to actually want to take these issues seriously rather than use them as sound bites and campaign material. And I don't see any interest right now in doing the hard work."331

A change in tax policy will not be beneficial unless the United States government uses the increased revenue to tackle the rising deficit. The European Union and other nations are onto a good idea by implementing a VAT, but unfortunately these governments have not utilized the VAT revenue wisely. Instead, these governments have stereotypically spent more and more money, using the VAT as a way to generate revenue to fund various social programs and wasteful spending. The United States needs to learn from the European Union and other countries and implement a VAT to increase revenue in order to close the budget deficit and pay down the national debt to sustainable levels. The United States national debt is growing by the hour; ${ }^{332}$ immediate action to reduce this debt is needed. ${ }^{333}$ In addressing the White House Debt Commission, Federal Reserve Chairman Ben Bernanke said, "given the significant costs and risks associated with a rapidly rising federal debt, our nation should soon put in place a credible plan for reducing deficits to sustainable levels over time." ${ }^{334}$ Once the United States implements a VAT, the government needs to refrain from wasting the new revenue by creating new entitlements or implementing new programs. Instead, the VAT money should be earmarked for paying down the national debt or making the already insolvent entitlements of Social Security and Medicaid solvent again.

330. Roger Runningen \& Mike Dorning, Volcker Panel Outlines Options for Tax Code Overhaul, BLOOMBERG (Aug. 28, 2010), http://www.bloomberg.com/news/2010-08-27/volckerpanel-to-give-obama-options-for-simplifying-taxes-broadening-base.html.

331. Id.

332. U.S. DEBT ClOCK, supra note 11.

333. Luca Di Leo, Bernanke: U.S. Needs Deficit Reduction Plan, Wall St. J. (Apr. 27, 2010), available at http://blogs.wsj.com/economics/2010/04/27/bernanke-us-needs-deficitreduction-plan/.

334. Id. 